\title{
Significance of C - Reactive Protein and Routine Analysis of Cerebrospinal Fluid in Children with Meningitis
}

\author{
Jagadevi $^{1}$, B. Saipriya ${ }^{1 *}$, K.R. Madhuri ${ }^{1}$, Anjana Gopi ${ }^{2}$ and Jagadeesh ${ }^{2}$ \\ ${ }^{1}$ Department of Microbiology, Basaveshwara Medical College and Hospital, Chitradurga, \\ Karnataka, India \\ ${ }^{2}$ Department of Microbiology, Kempegowda Institute of Medical sciences, Bangalore, \\ Karnataka, India \\ *Corresponding author
}

\begin{abstract}
A B S T R A C T
A 2-year prospective study was carried out on 110 children with clinical suspicion of meningitis where C-reactive protein (CRP) determination and routine cytochemical and

Keywords

Meningitis, Creactive protein, Cerebrospinal fluid, Children

Article Info

Accepted:

10 April 2018

Available Online:

10 May 2018 microbiological analysis of Cerebrospinal fluid (CSF) were done for all patients. The patients were divided into four groups: Pyogenic meningitis (PM), viral meningitis (VM), tubercular meningitis (TBM) and control groups. Among 110 cases of suspected meningitis, there were $62(56.36 \%)$ cases of meningitis, out of which $21(19.09 \%)$ were PM, 35(31.81\%) were VM, $06(5.45 \%)$ were TBM and the remaining $48(43.63 \%)$ were controls. Out of 21 cases of PM, CSF culture was positive in 9 (42.85\%), Latex agglutination test detected antigen in $14(66.66 \%)$ and Gram staining showed organisms in $13(61.90 \%)$. S.pneumoniae was the leading pathogen of PM, CSF LAT detected $6 / 21(28.57 \%)$ and CSF culture isolated $3 / 21(14.28 \%) S$. pneumoniae. The mean value of CSF CRP were $15.167 \pm 4.925$ in PM, 3.667 \pm 1.779 in TBM, and $2.557 \pm 0.998$ in VM. Statistically highly significant value $(\mathrm{p}<0.001)$ was observed when the mean of PM compared with other two groups. Quantitative estimation of CSF CRP is an easy and reliable, screening tool can be used for diagnosis of PM and to rule out VM or TBM in cases of uncertain diagnosis with high level of sensitivity and specificity.
\end{abstract}

\section{Introduction}

Meningitis is one of the most potentially serious infections occurring in infants and older children worldwide. In developing countries like India meningitis is major cause of morbidity and mortality because of delay in proper diagnosis and consequently delays in proper treatment. For the appropriate treatment of meningitis, differentiation of various types of meningitis is essential (Sharad Jain et al., 2010).

Acute meningitis is mainly caused by bacterial, viral, rickettsia or spirochete infection. Etiology of bacterial meningitis varies by age group and region of the world. Almost all microbes that are pathogenic to human beings have the potential to cause meningitis, but a relatively small number of 
pathogens (i.e., Group B Streptococcus, Escherichia coli, Listeria monocytogenes, Haemophilus influenzae type b, Streptococcus pneumoniae, and Neisseria meningitidis) account for most cases of acute bacterial meningitis in neonates and children, although the reasons for this association remain incompletely understood (Kwang Sik Kim, 2010).

Rapid and accurate diagnosis coupled with early appropriate therapy is the goals to overcome the high fatality and risk of neurological complications in children with meningitis. But early signs of meningitis are often subtle and non-specific and therefore the aid of laboratory diagnosis is considered an essential and critical step in early diagnosis and management of the patients.

Culture and sensitivity, Gram stain, cytology and biochemistry of CSF sample are traditionally being done to diagnose and to differentiate pyogenic from aseptic meningitis. Precise diagnosis of $\mathrm{ABM}$ is possible if the cerebrospinal fluid Gram stain or culture identifies the pathogen. Proper culture is affected by prior antibiotic therapy, delay in transportation and inoculation, long time (>24 hours) to isolate the organism and the facilities for doing cultures are not readily available in peripheral set up. Gram stain lacks specificity and has interpretative errors (Chowdhury et al., 1992). The drawback of Gram stain and culture were low yield in some centers and reported few positive cases in bacterial meningitis (Makoo et al., 2010). Latex agglutination test and other rapid diagnostic test are available but costly and present only in selective area.

The aetiologic diagnosis of meningitis remains a problem in clinical practice as CSF biochemical analysis and cellular response often overlap. There are some ambiguous cases between bacterial and viral meningitis such as neutrophilic predominate in viral meningitis (Bottner et al., 2002, Negrini et al., 2000, Somekh et al., 2003) or an unidentified pathogen in bacterial meningitis. Use of antibiotics makes the gram stain and culture negative and may alter the CSF cytology from neutrophilic to lymphocytic predominance. Thus, there is a need of rapid and aetiological diagnosis of meningitis for better clinical outcome. Tests like PCR and ELISA although helpful but are costly, not easily available, and not easily performed. Empirical antibiotic therapy is often given. In such circumstances the detection of C-reactive protein in CSF appears to provide a new dimension to the diagnosis of meningitis (Pemde et al., 1996).

CRP is one of several proteins that are often referred to as acute phase reactants. It is synthesized by the liver. It is secreted in large quantities within $6 \mathrm{hrs}$ of an acute inflammatory stimulus in serum or fluids associated with the affected tissues, a character that has long been employed for clinical purposes and is used to monitor changes in inflammation associated with many infections (Ram Mohan et al., 2015). Meningeal irritation stimulates CRP production. Once CRP enters the CSF it binds to the damaged tissues. Hence, increased serum CRP levels signify acute phase response, thus increased CSF CRP signifies meningeal involvement. A recent Metaanalysis suggested that a negative CRP test in either CSF or serum can be used with a very high probability to rule out bacterial meningitis (Ram Mohan et al., 2015).

Though available literatures have shown that, large number of studies conducted worldwide suggests C-reactive protein (CRP) is one of the most widely used inflammatory markers in the emergency department to distinguish bacterial from non-bacterial infections and CRP level in the CSF is higher in pyogenic meningitis as compared to non-pyogenic 
meningitis and hence aids in the differential diagnosis and management of meningitis (Mary et al., 2003; Hemavani et al., 2001; Shitemani et al., 2001; Jacques Wallach, 2000; Stearman et al.,1994; Przyjalkonski et al., 1996). But there are limited and inconsistent data supporting the same from our country and many of the previous studies in relation to CSF CRP and meningitis have used a Qualitative CRP assay. Hence there is a need for more systematic studies to generate valid data for improved quality of care and therefore the present study was designed to evaluate the diagnostic significance of inflammatory marker CRP and Routine CSF analysis in rapid diagnosis of bacterial and other meningitis in children.

\section{Materials and Methods}

110 clinically suspected meningitis patients admitted in the pediatric department were included in the study. A 2-year prospective study was carried in a tertiary care hospital. A detailed relevant history, clinical symptoms \& signs, details of treatment (antibiotics) taken prior to admission and duration of illness was recorded in the proforma. After admission all children (1month to 18 year) included in the study were subjected to routine blood investigations like total leukocyte count, differential leukocyte count, blood glucose, serum CRP and blood culture. A lumbar puncture was done on all children, samples of CSF were taken for total leukocyte count, differential leukocyte count, protein, glucose, CRP, Gram's staining, ZN staining, culture, antimicrobial susceptibility testing and Latex agglutination test (LAT). The LAT of bacterial antigen kit, was used to detect bacterial antigen of Group B Streptococcus, Hemophilus influenzae type B, Streptococcus pneumoniae, Neisseria meningitides group A and $\mathrm{C}$, and Escherichia coli, using the WELLCOGEN bacterial antigen kit manufactured by Remel Europe Limited, UK.
CRP testing: The quantitative estimation of CSF CRP level was done using the turbidometric method by a Hitachi Cobas 311 system with calibrators and internal controls provided by Roche diagnostics, instructions and cutoff values regarding CRP test were followed as per guideline provided by manufactures.

All 110 patients were divided into 4 groups based on clinical findings, CSF cytochemistry and microbiological assays (Prober et al., and Piyush Sadat et al., 2013).

Group1-Pyogenic meningitis (PM), was defined by a CSF leukocyte count of 100$10,000 / \mathrm{mm}^{3}$ with polymorpho neutrophils (PMNs) of $>50 \%$, CSF glucose $<40 \mathrm{mg} / \mathrm{dl}$ and a CSF protein level of $100-500 \mathrm{mg} / \mathrm{dl}$ or in cases where a CSF culture and/or Gram's staining or LAT have revealed bacteria.

Group 2-Viral meningitis (VM), was defined as those with a CSF pleocytosis of 50 to $<500$ cells/ $\mathrm{mm}^{3}$ with lymphocytic predominance $(>50 \%)$, and mildly elevated protein $(>40$ $\mathrm{mg} / \mathrm{dl})$, normal or slightly reduced sugar concentration with negative CSF bacterial culture and Gram stain.

Group 3- Tubercular meningitis (TBM), was defined as those with a history of contact with a sputum positive tuberculosis case, and a positive reaction to 5 tuberculin units of purified protein derivative, or in cases where a CSF culture and/or Ziehl Neelsen staining have revealed acid-fast bacilli and some reduction of glucose, moderately increased protein along with increased Lymphocytes, negative Gram stain and culture.

Group 4- Non- meningitis (control) group, included Clinically suspected meningitis patients those with a fever with convulsions but no meningitis, whose CSF examination yielded negative bacterial culture, negative 
Gram stain and normal CSF cytology and biochemistry and these convulsions were caused by epilepsy or febrile convulsions.

\section{Results and Discussion}

Total of 110 clinically suspected meningitis cases were studied. There were 62(56.36\%) cases of meningitis, out of which 21(19.09\%) cases were diagnosed as pyogenic meningitis, $35(31.81 \%)$ cases were diagnosed as viral meningitis, $06(5.45 \%)$ cases were diagnosed as tubercular meningitis and the remaining $48(43.63 \%)$ were non-meningitis/controls. Table 1 shows distribution of ages in both meningitis and non-meningitis group.

It is evident from the table that majority of cases i.e., $34(30.90 \%)$ were in the range of 112 month age. Lowest number of cases i.e., 19 $(17.27 \%)$ were in the range of 10-18 year age. The male, female ratio was 1.5:1 respectively. 67 cases were male, making up about $60.90 \%$ of the total cases with only 43(39.09\%) females. Male predominance noticed in all groups.

Out of 21 cases of pyogenic meningitis CSF culture was positive in $9(42.85 \%)$ cases, blood culture was positive in only $4(19.04 \%)$ cases, Latex agglutination test detected antigen in $14(66.66 \%)$ cases (Table 2) and Gram staining showed organisms in 13 $(61.90 \%)$ cases, which included Gram positive cocci in 10cases and 03 cases gram negative bacilli. CSF LAT could identify the maximum number of pyogenic meningitis cases 14 $(66.66 \%)$.

Study revealed that $S$. pneumoniae is the leading pathogen of PM, CSF LAT detected $6 / 21(28.57 \%)$ and CSF culture isolated 3/21 (14.28\%) S. pneumoniae followed by Group B Streptococci in $4 / 21(19.04 \%$ ) cases by CSF LAT and $2 / 21(9.52 \%$ ) cases by CSF Culture.

The cytological and biochemical examination of CSF of the studied cases, shown in the table 3 depicts $66.66 \%$ of cases of pyogenic meningitis had a CSF cell count of more than $400 / \mathrm{mm} 3$ as compared to $16.66 \%$ of tubercular meningitis \& $0 \%$ cases of viral meningitis. $50 \%$ cases of tubercular meningitis had a CSF cell count of less than $200 / \mathrm{mm} 3$ and $77.14 \%$ cases of viral meningitis and all the cases of control group had a CSF cell count $<100 / \mathrm{mm} 3$.Pyogenic meningitis cases had a predominantly neutrophilic CSF, that is neutrophil percentage of $95.23 \%$.On the other hand, viral meningitis \& tubercular meningitis cases had a predominantly lymphocytic CSF in $94.28 \%$ and $66.66 \%$ of cases respectively.

$47.61 \%$ of cases of pyogenic meningitis had a CSF protein level of $>200 \mathrm{mg} / \mathrm{dL}$, whereas this high levels of CSF protein were present only in $16.66 \%$ of cases of tubercular \& none of the cases of viral meningitis. $33.33 \%$ of cases of tubercular meningitis had a CSF protein range of $100-200 \mathrm{mg} / \mathrm{dL}$ and $82.85 \%$ of cases of viral meningitis group and all the cases of control group had a CSF protein level of $<100 \mathrm{mg} / \mathrm{d} \mathrm{L}$.

$76 \%$ of cases of pyogenic meningitis had a CSF glucose level $<30 \mathrm{mg} / \mathrm{d}$ whereas this low level of CSF glucose was present only in $33.33 \%$ of cases of tubercular meningitis \&none of the cases of viral meningitis. $66.66 \%$ of cases of tubercular meningitis had a CSF glucose range of $31-40 \mathrm{mg} / \mathrm{d} \mathrm{L}$ and $91.42 \%$ of cases of viral meningitis and all the cases of control group had a CSF glucose level $>40 \mathrm{mg} / \mathrm{d} \mathrm{L}$.

In the present study, table 4 depicts CSF-CRP level $>10 \mathrm{mg} / \mathrm{d} \mathrm{L}$ in $18(85.71 \%)$ cases out of 21 cases of pyogenic meningitis and only 3 cases had CSF-CRP $<10 \mathrm{mg} / \mathrm{dL}$. On the other hand most of the cases $(83.33 \%)$ of tubercular meningitis were having a CSF CRP level in the lower range of $<5 \mathrm{mg} / \mathrm{L}$ and one case in 
the range of $10-15 \mathrm{mg} / \mathrm{L}$. Similarly, in viral meningitis and control group, all the cases were having a CSF CRP in the range of $<5$ $\mathrm{mg} / \mathrm{L}$. The mean values of CRP were $15.167 \pm 4.952$ in pyogenic meningitis cases, $3.667 \pm 1.779$ in tubercular meningitis cases, and $2.557 \pm 0.998$ in viral meningitis cases. When PM was compared with TBM and VM cases statistically highly significant value $(\mathrm{p}<$ 0.001) was obtained.

Pyogenic meningitis group have been further subdivided in to culture positive and culture negative group, and their distribution in relation to CSF CRP level has been studied. The findings of this study (Table 5) indicated that $42.85 \%$ (9/21 cases) of the pyogenic meningitis cases were culture positive \& the remaining $57.14 \%$ (12/21 cases) were culture negative. The mean CRP value of culture positive pyogenic meningitis was $17.72 \pm 3.32$ and culture negative pyogenic meningitis was 12.96 \pm 5.03 . Statistical Difference of two means in culture positive PM and culture negative PM groups was $\mathrm{p}<0.02$, which indicated statistically significant $p$ value in our study.

The culture positive PM group had more cases 8 out of $9(88.88 \%)$ with CSF CRP levels more than $15 \mathrm{mg} / \mathrm{L}$ as compared to only 4 out of 12 $(33.33 \%)$ cases in culture negative PM group. The sensitivity of the CSF CRP test (Table 6) for diagnosing pyogenic meningitis was $95.23 \%, 85.71 \%, 57.14 \%$ for a cut-off value of $5 \mathrm{mg} / \mathrm{L}, 10 \mathrm{mg} / \mathrm{L}$ and $15 \mathrm{mg} / \mathrm{L}$ respectively and the specificity of the test was $97.56 \%$, $100 \%, 100 \%$ for a cut-off value of $5 \mathrm{mg} / \mathrm{L}, 10$ $\mathrm{mg} / \mathrm{L}$ and $15 \mathrm{mg} / \mathrm{L}$ respectively. Positive predictive value(PPV)were 95.23\%, 100\%, $100 \%$ for a cut-off value of $5 \mathrm{mg} / \mathrm{L}, 10 \mathrm{mg} / \mathrm{L}$, $15 \mathrm{mg} / \mathrm{L}$ respectively and Negative predictive value (NPV) were 97.56\%, 93.18\%, 82.00\% for a cut-off value $5 \mathrm{mg} / \mathrm{L}, 10 \mathrm{mg} / \mathrm{L}, 15 \mathrm{mg} / \mathrm{L}$ respectively.
More than two third of cases of meningitis occur in first two years of life owing to decreased immunity and high vascularity of brain (Xavier Saez-Llorens et al., 2004).

In the current study out of 110 suspected meningitis cases, 34(30.90\%) cases were below one year of age and 26(23.03\%), $31(28.18 \%), 19(17.17 \%)$ cases were in the range of 1-5 years, 5-10 years, 10-18 years age group respectively. The results of our study showed that infants were most vulnerable for meningitis. Similar findings have been reported by other workers (Russul Feihan Mussa, 2015 and Kalpana K. Malla et al., 2013). Male and female ratio in our study was 1.5: 1, well correlated with the studies of Modi Gaurav et al., (2011), George et al., (2002) and Abhijeet Awari et al., (2011) who have reported 1.5: 1, 1.5: 1 and 1.2: 1 respectively in their studies. All the studies show male preponderance including present study.

Although bacterial meningitis has a considerably lower incidence rate than viral/aseptic meningitis (Nigrovic et al., 2007; Dubos et al., 2008) accurate diagnosis and rapid treatment are necessary due to its hazardous nature.

Accordingly in our study, 21/110(19.09\%) cases were pyogenic meningitis, a higher number of cases were observed in viral meningitis $35 / 110(31.81 \%)$ and least cases $06(5.45 \%)$ were observed in tubercular meningitis group, these findings correlated with the Russul Feihan Mussa (2015) and Malla et al., (2013) studies.

Among the 21pyogenic meningitis cases, CSF culture was positive in $9(42.85 \%)$ cases and Culture was negative in $12 / 21(57.14 \%$ ) cases. Our study correlates with studies of the Mani et al., (2007) and Chinchankar et al., (2002), who reported $40.8 \%$, 50\% culture positivity respectively. 
Table.1 Different types of meningitis according to age groups

\begin{tabular}{|l|l|l|l|l|l|}
\hline Age & PM & VM & TBM & control & Total \\
\hline 01 month to 12 month & 07 & 12 & 0 & 15 & 34 \\
\hline 1-5 year & 05 & 10 & 01 & 10 & 26 \\
\hline 5-10 year & 06 & 07 & 02 & 16 & 31 \\
\hline 10-18 year & 03 & 06 & 03 & 07 & 19 \\
\hline Total & 21 & 35 & 06 & 48 & 110 \\
\hline
\end{tabular}

Table.2 Organisms identified in CSF and blood

\begin{tabular}{|l|l|l|l|}
\hline Organisms isolated & $\begin{array}{l}\text { CSF culture } \\
(\mathbf{n = 2 1 )}\end{array}$ & $\begin{array}{l}\text { Blood culture } \\
(\mathbf{n = 2 1})\end{array}$ & $\begin{array}{l}\text { CSF Latex agglutination test } \\
(\mathbf{n = 2 1})\end{array}$ \\
\hline S.pneumoniae & 3 & 1 & 6 \\
\hline Group B Streptococci & 2 & 0 & 4 \\
\hline E.coli & 1 & 1 & 1 \\
\hline E.fecalis & 1 & 1 & 0 \\
\hline K.pneumoniae & 1 & 1 & 0 \\
\hline C.koseri & 1 & 0 & 0 \\
\hline H.influenzae & 0 & 0 & 1 \\
\hline N.meningitidis & 0 & 0 & 1 \\
\hline Total & $9 / 21(42.85 \%)$ & $4 / 21(14.04 \%)$ & $14 / 21(66.66 \%)$ \\
\hline
\end{tabular}

Table.3 Cytological and biochemical examination of CSF in different types of meningitis

\begin{tabular}{|c|c|c|c|c|c|}
\hline $\begin{array}{c}\text { Serial } \\
\text { no }\end{array}$ & Parameters & $\begin{array}{l}\operatorname{PM}(\mathbf{n}=21) \\
\text { No }(\%)\end{array}$ & $\begin{array}{c}\operatorname{VM}(\mathbf{n}=\mathbf{3 5}) \\
\text { No }(\%)\end{array}$ & $\begin{array}{c}\text { TBM(n=6) } \\
\text { No }(\%)\end{array}$ & $\begin{array}{c}\text { Control }(\mathrm{n}=48) \\
\text { No }(\%)\end{array}$ \\
\hline \multirow[t]{6}{*}{1} & CSF cell count $\left(/ \mathrm{mm}^{3}\right)$ & & & & \\
\hline & $<100$ & $00(0)$ & $27(77.14)$ & $00(0)$ & 48 (100) \\
\hline & $100-200$ & $01(4.76)$ & $05(14.28)$ & $03(50.00)$ & $00(0)$ \\
\hline & $201-300$ & $02(9.52)$ & $02(5.71)$ & $01(16.66)$ & $00(0)$ \\
\hline & $301-400$ & 04 (19.04) & $01(2.87)$ & $01(16.66)$ & $00(0)$ \\
\hline & $>400$ & $14(66.66)$ & $00(0)$ & $01(16.66)$ & $00(0)$ \\
\hline 2 & $\begin{array}{l}\text { CSF Polymorpho } \\
\text { neutrophil predominant }\end{array}$ & $20(95.23)$ & $02(5.71)$ & $02(33.33)$ & $00(0)$ \\
\hline 3 & $\begin{array}{l}\text { CSF Lymphocyte } \\
\text { predominant }\end{array}$ & $01(4.76)$ & $33(94.28)$ & $04(66.66)$ & $7(14.58)$ \\
\hline \multirow[t]{5}{*}{4} & $\begin{array}{l}\text { CSF protein } \\
\text { levels }(\mathrm{mg} / \mathrm{dl})\end{array}$ & & & & \\
\hline & $<100$ & $00(0)$ & $30(82.85)$ & $01(16.66)$ & $48(100)$ \\
\hline & $101-150$ & $04(19.04)$ & $04(11.42)$ & $02(33.33)$ & $00(0)$ \\
\hline & $151-200$ & $07(33.33)$ & $01(2.85)$ & $02(33.33)$ & $00(0)$ \\
\hline & $>200$ & $10(47.61)$ & $00(0)$ & $01(16.66)$ & $00(0)$ \\
\hline \multirow[t]{5}{*}{5} & $\begin{array}{l}\text { CSF glucose } \\
\text { levels }(\mathrm{mg} / \mathrm{dl})\end{array}$ & & & & \\
\hline & $<10$ & $01(4.76)$ & $00(0)$ & $00(0)$ & $00(0)$ \\
\hline & $11-30$ & $15(71.42)$ & $00(0)$ & $02(33.33)$ & $00(0)$ \\
\hline & $31-40$ & $05(23.80)$ & $03(8.57)$ & $04(66.66)$ & $00(0)$ \\
\hline & $>40$ & $00(0)$ & $32(91.42)$ & $00(0)$ & 48 (100) \\
\hline
\end{tabular}


Table.4 Showing CSF CRP level and distribution of cases in different type of Meningitis

\begin{tabular}{|l|l|l|l|l|l|}
\hline & Range of CSF CRP $(\mathrm{mg} / \mathrm{L})$ & \multicolumn{1}{|c|}{ PM } & VM & TBM & Total \\
\hline 1 & $0-5.0$ & 01 & 35 & 05 & 41 \\
\hline $\mathbf{2}$ & $5.1-10.0$ & 02 & 00 & 01 & 03 \\
\hline 3 & $10.1-15.0$ & 06 & 00 & 00 & 06 \\
\hline 4 & $15.1-20.0$ & 08 & 00 & 00 & 08 \\
\hline 5 & $>20.0$ & 04 & 00 & 00 & 04 \\
\hline Total & ---- & 21 & 35 & 06 & 62 \\
\hline & Mean CSF CRP(mg/L) & 15.167 & 2.557 & 3.667 & \\
\hline & Standard deviation & 4.925 & 0.998 & 1.779 & \\
\hline
\end{tabular}

Pyogenic meningitis group: Mean $=15.167, \mathrm{SD}= \pm 4.925$

Viral meningitis group: Mean $=2.557, \mathrm{SD}= \pm 0.998$

TB meningitis group: Mean $=3.667, \mathrm{SD}= \pm 1.779$

\{Pyogenicvs viral meningitis: $p$ value $<0.0001$, Statistically highly significant

Pyogenic vs TB meningitis: $p$ value $<0.0001$, statistically highly significant.

Viral vs TB meningitis: $p$ value $=0.032$, Statistically significant $\}$

Table.5 Relation of CSF CRP with CSF culture in pyogenic meningitis

\begin{tabular}{|c|c|c|c|c|}
\hline $\begin{array}{c}\text { Serial } \\
\text { No }\end{array}$ & $\begin{array}{c}\text { Range of CSF } \\
\text { CRP(mg/L) }\end{array}$ & $\begin{array}{l}\text { PM culture } \\
\text { positive }\end{array}$ & $\begin{array}{l}\text { PM culture } \\
\text { negative }\end{array}$ & Total \\
\hline 1 & $0-5.0$ & 00 & 01 & 01 \\
\hline 2 & $5.1-10.0$ & 00 & 02 & 02 \\
\hline 3 & $10.1-15.0$ & 01 & 05 & 06 \\
\hline 4 & $15.1-20.0$ & 05 & 03 & 08 \\
\hline 5 & $>20.0$ & 03 & 01 & 04 \\
\hline \multirow[t]{3}{*}{ Total } & ----- & 09 & 12 & 21 \\
\hline & Mean & 17.72 & 12.96 & ---- \\
\hline & Std.deviation & 3.32 & 5.03 & \\
\hline
\end{tabular}

Culture Positive PM group, Mean $=17.72, \mathrm{SD}= \pm 3.32$

Culture Negative PM group, Mean $=12.96, \mathrm{SD}= \pm 5.03$

\{Statistical Diff of two means in above two groups $\mathrm{p}<0.02$, Statistically highly significant $\}$.

Table.6 Showing sensitivity, specificity, PPV, NPV for different CSF CRP levels as a diagnostic test for pyogenic meningitis

\begin{tabular}{|l|l|l|l|l|l|}
\hline $\begin{array}{c}\text { SI } \\
\text { No }\end{array}$ & $\begin{array}{c}\text { Level of CSF CRP used as a } \\
\text { cut-off for Diagnosing } \\
\text { PM(mg/ L) }\end{array}$ & $\begin{array}{c}\text { Sensitivity } \\
\%\end{array}$ & $\begin{array}{c}\text { Specificity } \\
\%\end{array}$ & $\begin{array}{c}\text { PPV } \\
\%\end{array}$ & $\begin{array}{c}\text { NPV } \\
\%\end{array}$ \\
\hline 1 & 5 & 95.23 & 97.56 & 95.23 & 97.56 \\
\hline 2 & 10 & 85.71 & 100 & 100 & 93.18 \\
\hline 3 & 15 & 57.14 & 100 & 100 & 82.00 \\
\hline
\end{tabular}


$S$. pneumoniae was the most common etiological agent of pyogenic meningitis in the present study accounting for 7/21(33.33\%) cases followed by Group B Streptococci in $4(19.04 \%)$ cases and $H$. influenzae B in $2(9.52 \%)$ cases. Similar isolation rates have been reported by other workers (Gudza-Mugabe et al., 2015; Deivanayagam et al., 1993).

In the present study, percentage positivity of Gram stain was $61.90 \%$ and $38.09 \%$ of cases were Gram stain negative. Our study correlates with studies of the other authors, Mani et al., (2007), Chinchankar et al., (2002) who reported $65.71 \%$, 67\% Gram stain positivity respectively.

Latex agglutination test was positive in 14 cases $(66.66 \%)$ of pyogenic meningitis. Out of these 14 cases, S. pneumoniae was isolated in 6 cases followed byGroup B Streptococci 4 cases, H.influenzae 2 cases, N.meningitidis and E.fecalis in one case each. $33.33 \%$ were LAT negative. Our study correlates with studies of the other authors Shivaprakash et al., (2004), Chinchanakar et al., (2002) and Mani et al., (2007) who reported 69.09\%, $78 \%$ and $54.6 \%$ LAT positivity respectively. In developing countries like India where a majority of neonatal meningitis is caused by Enterobacteriaceae, culture is superior to LAT in neonatal meningitis as the latter is not designed to detect Enterobacteriaceae other than $E$. coli, besides, the cost of LAT is the major limiting factor.

Cytological characteristics of CSF in patients with pyogenic meningitis showed much

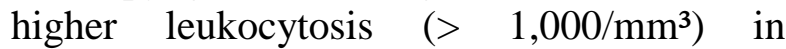
$11 / 21(57.14 \%) \quad$ cases and polymorphoneutrophilic leukocytosis encountered in 95.23\%. As expected, CSF pleocytosis was at lower range $\left(<100 / \mathrm{mm}^{3}\right)$ in viral meningitis $29 / 35(82.85 \%)$ and tubercular meningitis $1 / 6(16.66 \%)$ with
Lymphocytic predominance of $94.28 \%$ and $66.66 \%$ in viral meningitis and tubercular meningitis respectively and in the control group all the values were found within normal range. These findings were consistent with the findings of Rabab Fouad et al., (2014), Kalpana et al., (2013), Piyush Sadat et al., (2013).

Biochemical characteristics of CSF in patients with pyogenic meningitis showed much elevated protein level $(47.61 \%$ of cases had protein level of $>200 \mathrm{mg} / \mathrm{dL}$ ) than that of viral meningitis $(82.85 \%$ of cases had protein level $<100 \mathrm{mg} / \mathrm{d}$ L) and tubercular meningitis $(66.66 \%$ of cases had a protein level of $100-$ $200 \mathrm{mg} / \mathrm{d}$ L) with lower protein level. As expected CSF glucose was much lower in pyogenic meningitis (76\% of cases had a CSF glucose level $<30 \mathrm{mg} / \mathrm{d}$ ) than that of viral meningitis and tubercular meningitis $(91.42 \%$ of VM and $33.33 \%$ of TBM cases had glucose $>40 \mathrm{mg} / \mathrm{d} \mathrm{L}$ ) and in the control group all the values were found within normal range. These findings were consistent with the findings of Rabab Fouad et al., (2014), Kalpana et al., (2013) and Piyush Sadat et al., (2013).

We studied the usefulness of CRP in the differential diagnosis of meningitis of varying etiology. Higher percentage positivity of CSF CRP in pyogenic meningitis have been documented in our study that is $95.23 \%$ (20 of 21 cases) on the other hand CSF CRP was negative in all viral meningitis cases, 5 out of 6 tubercular meningitis cases and all control group cases. Similar studies conducted by other workers Hemavani et al., (2001), Belal Uddin et al., (2009), Piyush Sadat et al., (2013), Malla et al., (2013), Rafeza Khanam et al., (2012), Sharad Banasal et al., (2013), observed that CRP levels in CSF were significantly lower in patients with nonpyogenic meningitis compared to pyogenic meningitis. These studies conclude that CSF CRP estimation is a useful marker to 
differentiate pyogenic from non-pyogenic meningitis; however, it cannot differentiate between tuberculosis, fungal, and viral meningitis. These authors also observed negative response in all the cases of aseptic/viral meningitis and control groups in their study.

In our study quantitative estimation of CRP in CSF was done by turbidometry method. The pyogenic meningitis group had a mean CSF CRP level of $15.35 \pm 7.12$ which is much higher as compared to the mean levels in other two groups that is $3.33 \pm 22.92$ in $\mathrm{TB}$ meningitis group and $2.50 \pm 25.00$ in viral meningitis group.

These findings correlated with Sharad Jain et al., (2016) reported the mean Value of CRP $32.50645 \pm 2.032886$ in pyogenic meningitis cases, $1.543373 \pm 0.195181$ in tubercular meningitis cases, and $2.420833 \pm 0.357502$ in viral meningitis cases. They observed statistically significantly higher value with pyogenic meningitis cases compared to TBM and VM cases $(\mathrm{p}<0.001)$ which again was very consistent with our study.

Shrad Bansal et al., 2013 found the quantitative value of CSF CRP significantly higher in bacterial meningitis group. The difference between pyogenic meningitis and control group $(\mathrm{p}<0.001)$, between pyogenic meningitis and viral meningoencephalitis $(p<0.001)$ and between pyogenic meningitis and tubercular meningitis were highly significant $(\mathrm{p}<0.001)$. Similarly in our study also ( $\mathrm{p}<0.001)$ was observed with pyogenic meningitis cases when compared with TBM and VM cases. So the CSF CRP results of our study are consistent with many previous studies. Author concludes that CRP level is a useful tool for differentiating between pyogenic meningitis and viral meningitis and also tubercular meningitis in cases of uncertain diagnosis and for looking for complications of bacterial meningitis. In the present study the mean CSF CRP levels in the culture positive PM $(17.72 \mathrm{mg} / \mathrm{L})$ group was higher as compared to culture negative PM $(12.96 \mathrm{mg} / \mathrm{L})$ group. This difference in two means ( $p<0.02$ ) was found to be statistically highly significant. Thus, our study suggests that those with culture positive pyogenic meningitis have a higher CRP levels as compared to those who are culture negative.

In our study the maximum sensitivity of the CSF CRP test for diagnosing pyogenic meningitis was achieved at a cut-off value of $5 \mathrm{mg} / \mathrm{L}$ (95.23\% - sensitivity) at this level of sensitivity the other test characteristics are also acceptable making it a good screening test at this cut-off level. The maximum specificity of the test is at the level of $10 \mathrm{mg} / \mathrm{L}$ $\& 15 \mathrm{mg} / \mathrm{L}(100 \%$ - specificity) but this is at the expense of slightly low sensitivity $85.71 \%, 57.14 \%$ respectively. Thus, it is clear that the ideal cut-off value that should be used for diagnosing pyogenic meningitis by CSF CRP level should lie between $5-15 \mathrm{mg} / \mathrm{L}$. Maximum Positive predictive value $(100 \%)$ of the test is at the level of $10 \mathrm{mg} / \mathrm{L}$ and 15 $\mathrm{mg} / \mathrm{L}$ and Negative predictive value at this cut -off level were $93.18 \%, 82.00 \%$ respectively. Similar findings have been reported by other workers Sharad Jain et al., (2016), Sandeep Aharwar et al., (2016) and Kalpana et al., (2013).

From the preceding study results, the author came to a conclusion that although culture is the gold standard for diagnosis of pyogenic meningitis it has some limitation. Routine use of CSF CRP seems to be easy, reliable, rapid, screening tool for suspected meningitis to differentiate acute pyogenic from viral meningitis consistently and with high level of sensitivity and specificity. A CSF CRP level of more than $15 \mathrm{mg} / \mathrm{L}$ by turbidometric method can be used to confirm the diagnosis of pyogenic meningitis and rule out tubercular 
or viral meningitis. A level below $5 \mathrm{mg} / \mathrm{L}$ can be used to rule out a diagnosis of pyogenic meningitis. It is not an alternative of CSF culture.

\section{References}

Abhijeet Awari, sunitanighute. 2012. Incidence of bacterial meningitis with special reference to latex agglutination test. Journal of recent advances in applied sciences (jraas); 27:65-68.

Amulya C Belagavi, M Shalini. 2011. Cerebrospinal Fluid C Reactive Protein and Adenosine Deaminase in Meningitis in Adults. JAPI VOL. 59:557-560.

Anil Kumar T, K Punith, Santosh Revankar, Ravi Kumar VN, Medha Y Rao, U Sudhir. 2010. Significance of Cerebrospinal Fluid C-reactive Protein Level in Pyogenic and Non-pyogenic Meningitis in Adults. JIACM. 11(2): 112-5.

Belal Uddin, M., Manjira Rahman, A B Siddique. 2009. Usefulness of CSF C Reactive protein in Differentiating Pyogenic and Aseptic Meningitis. The Journal of Teachers Association. 22.1.

Bottner A, Daneschnejad S, Handrick W. 2000. A season of aseptic meningitis in Germany: epidemiologic, clinical and diagnostic aspects. Pediatr Infect Dis J 21: 1126-32.

Chinchankar N, Mane N, Bhave S, Bapat S, Bardekar A, Pandit A, et al., 2002. Diagnosis and outcome of acute bacterial meningitis in early childhood. Indian Pediatric 39: 914-92.

Chowdhury MZU, Rahman KM, Miah RA, Sattar H, Hussain T. 1992. Bacterial Meningitis in children. Bangladesh Medical Journal. 21: 3-7.

Ciji N. George, S. Letha and Sushma Bai. 2002. A Clinical study of chronic morbidity in children following pyogenic meningitis. Indian paediatrics. 39: 663-667.

Col PL Prasad, Brig MNG Nair, Lt Col AT Kalghatgi. 2005. Childhood Bacterial Meningitis and Usefulness of C-reactive Protein. MJAFI, Vol. 61, No. 1, 2005

Devianayagam N, Ashok TP, Nedunchelian K, Ahamed SS, Mala N. 1993. Bacterial meningitis: Diagnosis by latex agglutination test and clinical features. Indian Pediatr., 30: 495-500

Gudza-Mugabe M, Robertson V, Mapingure MP, Mtapuri-Zinyowera S, Mavenyengwa RT.2015.Bacterial Paediatric Meningitis Laboratory Diagnosis. J Med MicrobDiagn 4: 183. doi: 10.4172/21610703.1000183

Helmy A. Qurtom, MRCP; Qusay A. AlSalah, MRCP; Mahmoud M. Lubani, MD; Kamel I. Doudin, MD; Dinesh C. Sharda, FRCP; Areckal I. John, MD. 1989. The Value of C-Reactive Protein in Children with Meningitis. Annals of Saudi Medicine, Vol 9 No. 2.

Hemavani N, Chitnis D, Joshi SP.2001.Creactive protein in $\mathrm{CSF}$ and its role in differential diagnosis of meningitis. Indian Journal of Medical Microbiology. 19 (1): 26-9.

Jacques Wallach. Interpretation of diagnostic tests. 2000. Lippincott William and Wilkins 7: 50-51. 3.

Kalpana K. Malla, Tejesh Malla, K. Seshagiri Rao, Sahisnuta Basnet, Ravi Shah. 2013. Is Cerebrospinal Fluid C-reactive Protein a Better Tool than Blood Creactive Protein in Laboratory Diagnosis of Meningitis in Children? Sultan Qaboos University Med J. Vol. 13, Issue. 1, pp. 93-99, Epub. 27th Feb 13.

Makoo Z B, Ahadi N, Hadsni A. 2010. CSF ferritin for differentiation of aseptic \& bacterial meningitis in adults. Am $\mathbf{J}$ Infect Dis.6:98 
Mani R, Pradhan S, Nagarathna S, Wasiulla R, Chandramukhi A. 2007. Bacteriological profile of community acquired acute bacterial meningitis: A ten year retrospective study in a tertiary neurocarecentre South India. Indian $J$ of Med Microbiol 25: 108-114.

Mary R, Veinberg F, Couderc R. 2003. Acute meningitis, acute phase proteins and procalcitonin. Ann BiolClin (Paris). 61 (2): 127-37. 2.

Modi Gaurav B, Patel Komal D, Soni Sumeeta T, Patel Kanu J, Mangukiya Jayasukh D, Jain Pooja S. 2012. Bacteriological profile of pyogenic meningitis in tertiary care hospital, Ahmedabad. National journal of medical research. Volume 2, Issue 3: 313-17.

Negrini B, Kelleher KJ, Wald ER. 2000. Cerebrospinal fluid findings in aseptic versus bacterial meningitis. Pediatrics. 105: 316-9

Pemde HK, Harish K. 1996.C-Reactive Protein in Childhood Meningitides. Indian J Pediatr 63: 73-7.

Piyush Sadat, Snehal V. Patel, Kruti Shah. 2013. Role of CSF-CRP as a Bedside Diagnostic Test in Children with Meningitis. NHL Journal of Medical Sciences. Vol. 2. issue 1.

Prober CG, Dyner LL. Central nervous system infections. In: Klegman RM, Stanton BF, St. Geme JW, Schor NF, Behrman RE, Eds. Nelson Textbook of Pediatrics. $19^{\text {th }}$ ed. Philadelphia, PA: WB Saunders press, 2012. p. 2088.

Przyjalkonski W. 1996.CRP and its significance in purulent meningitis. Neurol Neurochir Pol. 30 (1): 177.

Rabab Fouad, Marwa Khairy, Waleed Fathalah, Taha Gad, Badawy El-Kholy, and Ayman Yosry. 2014. Role of Clinical Presentations and Routine CSF Analysis in the Rapid Diagnosis of Acute Bacterial Meningitis in Cases of
Negative Gram Stained Smears.Journal of Tropical Medicine Volume 2014, Article ID 213762, 7 pages

Rafeza Khanam1, Mohammad Hanif2, MD. Mahbubul Hoque3, Muhammad Tawfique4, A.S.M. NawshadUddin Ahmed. 2012. Role of CSF C-Reactive Protein for the Differentiation of Bacterial Meningitis from Aseptic Meningitis in Children. Bangladesh J Child Health. 36(3): 126-132

Ram Mohan Rao, M., and Syam D Gopal. 2015. C-Reactive Protein - A critical Review. Int.J.Curr.Microbiol.App.Sci. 4(12): 55-61

RussulFeihan Mussa.2015. The Significance of Serum C-Reactive Protein in Childhood Acute Meningitis. Medical Journal of Babylon.Vol12- No. 3: 730738.

Sharad Jain, RashmiNayak, Anand Sharma.2016.Role of C- reactive proteins in cerebro-spinal fluid in differentiating pyogenic from nonpyogenic meningitis. Int J Res Med Sci. 4(7): 2839-2842

Sharad Bansal, Rimzim Gupta, P.P. Gupta, M. K. Kakkar, A.K. Malhotra. 2013. "Quantitative levels of C- Reactive Protein in Cerebrospinal Fluid in Children with Bacterial and Other Meningitis". Journal of Evolution of Medical and Dental Sciences. Vol2, Issue 25, June 24; Page: 4594-4598.

Shitemani N, Shitemani K, Mori M. 2001. Levels of three inflammation markers, C-reactive protein, serum amyloid A protein and procalcitonin, in the serum and cerebrospinal fluid of patients with meningitis. Scan J Clin Lab Invest. 61(7): $567-74$

Shivaprakash MR, Rajagopal V, Nagarathna S.2004. Latex agglutination test in the diagnosis of pyogenic meningitis. J Commun Dis. 36(2): 127-131. 
Somekh E, Cesar K, Handsher R. 2003. An outbreak of echovirus 13 meningitis in central Israel. Epidemiol Infect.130: 257-62

Stearman M, Southgate HJ.1994.The use of cytokine and C-reactive protein measurements in cerebrospinal fluid during acute infective meningitis. Ann Clin. Biochem. 31 (Pt 3): 255-61.

Sultana Shameem, VinodKumar CS, Neelagund YF.2008. Bacterial Meningitis: Rapid Diagnosis And Microbial Profile: A Multicentered Study. J. Commun. Dis. 40 (2). 111-12 Xavier Saez-Llorens and George H. 2004. McCracken Jr. Infectious disease of children. 11th edn. Philadelphia: Mosby publication.

\section{How to cite this article:}

Jagadevi, B. Saipriya, K.R. Madhuri, Anjana Gopi and Jagadeesh. 2018. Significance of C Reactive Protein and Routine Analysis of Cerebrospinal Fluid in Children with Meningitis. Int.J.Curr.Microbiol.App.Sci. 7(05): 1236-1247. doi: https://doi.org/10.20546/ijcmas.2018.705.150 